\title{
KONSUMSI CAIRAN PERIODE LATIHAN DAN STATUS HIDRASI SETELAH LATIHAN PADA ATLET SEPAK BOLA REMAJA
}

\author{
Dittasari Putriana, Fillah Fithra Dieny*) \\ Program Studi Ilmu Gizi Fakultas Kedokteran Universitas Diponegoro \\ J1.Dr.Sutomo No.18, Semarang, Telp (024) 8453708, Email : gizifk@ undip.ac.id
}

\begin{abstract}
Background: Football athletes perform high intensity exercise. They have potential to become dehydrated if fluid loss due to an increase in expenditure of water through sweating and breathing was not matched by adequate fluid intake. Adolescents athletes have a higher risk of dehydration than adult athletes. The purpose of this study was to analyze the correlation between fluid intake in exercise period with hydration status after exercise in adolescents football athletes.

Methods: An observational study with cross-sectional design that involved 47 male adolescent football athletes (age 13-16 years old) in the Football School of Diponegoro University Semarang. Subject was selected by simple random sampling. Data was collected including subject characteristics, fluid intake, body mass loss, urine volume, sweat loss during exercise, and hydration status after exercise. Football exercise performed for 70 minutes. Fluid intake in exercise period was measured using a food recall, sweat loss during exercise was calculated using the formula and hydration status after exercise was measured by urine specific gravity.

Results: The mean fluid intake in exercise period $(1678.77 \pm 457.99 \mathrm{ml})$ less than the requirement $(2400-3400 \mathrm{ml})$. The mean sweat loss were 1364,19 $\pm 448,68 \mathrm{ml}$. All athletes were dehydrated, most had significant dehydration (89.4\%) and others had minimal dehydration (10.6\%). There was significant correlation between the fluid intake in exercise period and hydration status after exercise $(p<0,05)$, but no significant correlation between sweat loss during exercise and hydration status after exercise in adolescent football athletes $(p>0,05)$.

Conclusion: There was significant correlation between the fluid intake in exercise period and hydration status after exercise in adolescent football athletes.
\end{abstract}

Keywords: fluid intake; hydration status; football; adolescent athletes

\begin{abstract}
ABSTRAK
Latar Belakang : Atlet sepak bola merupakan atlet yang melakukan olahraga dengan intensitas tinggi. Atlet sepak bola berpotensi untuk mengalami dehidrasi apabila kehilangan cairan karena peningkatan pengeluaran air melalui keringat dan pernafasan tidak diimbangi dengan konsumsi cairan yang cukup. Atlet remaja memiliki risiko dehidrasi lebih tinggi daripada atlet dewasa. Tujuan penelitian ini untuk menganalisis hubungan konsumsi cairan pada periode latihan dengan status hidrasi setelah latihan pada atlet sepak bola remaja.

Metode : Penelitian observasional dengan desain cross-sectional yang melibatkan 47 atlet sepak bola remaja lakilaki (usia 13-16 tahun) di Sekolah Sepak Bola Universitas Diponegoro Semarang. Subjek dipilih dengan simple random sampling. Data yang dikumpulkan meliputi karakteristik subjek, konsumsi cairan, kehilangan berat badan, volume urin, keringat yang hilang selama latihan dan status hidrasi setelah latihan. Latihan pertandingan sepak bola dilakukan selama 70 menit. Konsumsi cairan pada periode latihan diukur dengan menggunakan food recall, keringat yang hilang selama latihan dihitung menggunakan rumus dan status hidrasi setelah latihan diketahui dengan pemeriksaan berat jenis urin.

Hasil : Rerata konsumsi cairan pada periode latihan (1678,77士457,99 ml) masih kurang dari kebutuhan (2400-

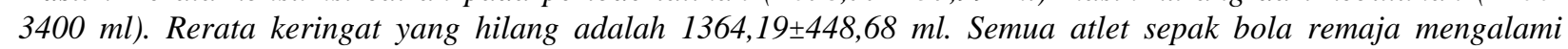
dehidrasi, sebagian besar mengalami significant dehydration $(89,4 \%)$ dan yang lain mengalami minimal dehydration (10,6\%). Terdapat hubungan yang bermakna antara konsumsi cairan pada periode latihan dan status hidrasi setelah latihan $(p<0,05)$, tetapi tidak terdapat hubungan antara keringat yang hilang selama latihan dan status hidrasi setelah latihan pada atlet sepak bola remaja $(p>0,05)$.
\end{abstract}

Simpulan : Terdapat hubungan yang bermakna antara konsumsi cairan pada periode latihan dan status hidrasi setelah latihan pada atlet sepak bola remaja.

Kata kunci : konsumsi cairan; status hidrasi; sepak bola; atlet remaja

\section{PENDAHULUAN}

Prestasi olahraga di Indonesia cenderung mengalami pasang surut yang tidak terkontrol dan tidak stabil, bahkan akhir-akhir ini terus mengalami penurunan di ajang internasional seperti pada kejuaraan Sea Games dan Asian Games. Penurunan prestasi olahraga yang diraih Indonesia dalam event olahraga internasional ditandai dengan penurunan jumlah perolehan medali maupun peringkat. ${ }^{1}$ Prestasi atlet 
dipengaruhi beberapa faktor, salah satunya adalah yang berkaitan dengan gizi. ${ }^{2,3}$ Salah satu unsur gizi yang penting adalah air. Konsumsi cairan yang tidak mencukupi dapat mempengaruhi kelelahan, status hidrasi, dan performa atlet. ${ }^{4,5,6}$

Kelelahan dapat dialami oleh semua atlet di berbagai cabang olahraga, salah satunya adalah atlet sepak bola. Sepak bola adalah olahraga yang memiliki intensitas tinggi dan sering disebut sebagai olahraga ketahanan (endurance). ${ }^{4}$ Intensitas yang tinggi pada olahraga sepak bola mengakibatkan para atletnya sering mengalami kelelahan sebelum pertandingan selesai. ${ }^{7}$ Kelelahan terjadi akibat banyaknya keringat yang keluar saat pertandingan dan tidak diimbangi dengan konsumsi cairan yang cukup untuk menjaga keseimbangan cairan tubuh sehingga dapat meningkatkan risiko dehidrasi. ${ }^{5}$

Dehidrasi adalah kehilangan cairan tubuh yang berlebihan karena penggantian cairan yang tidak cukup akibat asupan yang tidak memenuhi kebutuhan tubuh dan terjadi peningkatan pengeluaran air. ${ }^{8,9}$ Beberapa penelitian menunjukkan bahwa dehidrasi memiliki efek negatif terhadap performa olahraga. ${ }^{10,11}$ Penelitian di Turki menunjukkan bahwa pengeluaran keringat dan tingkat dehidrasi menjadi lebih tinggi ketika latihan sepak bola dilakukan pada cuaca panas. ${ }^{12}$ Rata-rata atlet sepak bola kehilangan 1,59\% berat badan saat menjalani latihan sepak bola pada musim panas dan $1,62 \%$ saat menjalani latihan sepak bola pada musim dingin. ${ }^{13}$ Kehilangan berat badan saat latihan menunjukkan cairan yang hilang selama latihan. ${ }^{11,14}$ Beberapa penelitian menunjukkan bahwa tidak semua atlet terhidrasi dengan baik sebelum dan setelah latihan dilakukan. ${ }^{15,16}$ Penelitian di Yunani menunjukkan prevalensi dehidrasi sebesar $87,5 \%$ pada atlet sepak bola remaja selama latihan sepak bola dengan berat jenis urin $>1.020 \mathrm{~g} / \mathrm{dl} .{ }^{17}$ Berdasarkan osmolalitas urin dan berat jenis urin, ditemukan bahwa atlet sepak bola mengalami hipohidrasi sebelum dan setelah latihan. ${ }^{17,18}$ Studi di Turki pada 40 atlet sepak bola yang menjalani latihan selama 90 menit pada musim dingin menunjukkan bahwa 35\% terhidrasi dengan baik dan lebih dari separuh atlet mengalami hipohidrasi sebelum latihan serta status hidrasi tubuh memburuk setelah latihan. ${ }^{15} \mathrm{Hal}$ ini menunjukkan bahwa atlet yang memulai latihan dengan status hidrasi yang baik belum tentu terhidrasi dengan baik pula setelah latihan. Status hidrasi yang baik dapat dicapai atlet dengan mengonsumsi cairan yang cukup sebelum, selama dan setelah latihan.
Saat ini berbagai cabang olahraga di Indonesia mengalami perkembangan yang baik. Perkembangan yang baik harus sejalan dengan kualitas pemain. Oleh karena itu, diperlukan atlet remaja atau junior yang nantinya dapat berperan dalam meningkatkan kemajuan olahraga dalam ajang nasional maupun internasional. Menjadi seorang atlet saat usia remaja tidak mengurangi risiko terjadinya penurunan performa olahraga. Selain itu, atlet remaja memiliki risiko dehidrasi lebih tinggi daripada atlet dewasa. ${ }^{19,20}$ Atlet remaja berisiko kehilangan cairan saat berolahraga disebabkan oleh produksi panas tubuh lebih tinggi dan lebih mudah menyerap panas karena mempunyai rasio permukaan tubuh yang lebih besar dibandingkan atlet dewasa sehingga simpanan cairan yang ada di dalam tubuh digunakan untuk menurunkan panas tubuh. ${ }^{20}$

Berdasarkan penelitian pada atlet sepak bola, sebagian besar atlet mengonsumsi cairan yang kurang saat latihan maupun pertandingan. 5,12,16,18,21 Atlet harus mengonsumsi cairan yang cukup untuk menghindari cedera akibat panas tubuh yang berlebihan dan mengembalikan cairan yang hilang melalui keringat untuk mencegah terjadinya dehidrasi. American College of Sports Medicine (ACSM), National Athletic Trainers Association (NATA) dan American Dietetic Asosiation (ADA) merekomendasikan konsumsi cairan atlet pada periode latihan (sebelum, selama dan setelah latihan) adalah 2,4-3,4 liter. ${ }^{14}$ Rata-rata konsumsi cairan atlet sepak bola remaja usia 14-18 tahun di Brazil saat latihan adalah 1,12-1,7 liter.,.$^{5,8,21}$ Sedangkan saat latihan, atlet sepak bola remaja di Brazil kehilangan keringat sebanyak 2-3 liter..$^{5,8,21}$ Hal ini menunjukkan bahwa konsumsi cairan tersebut belum terpenuhi dan belum mampu untuk menggantikan cairan yang hilang melalui keringat selama latihan.

Pengeluaran cairan yang berlebih dan tidak diimbangi cairan yang cukup akan mempengaruhi status hidrasi atlet sepak bola remaja. Namun, penelitian ini masih jarang dilakukan di Indonesia. Berdasarkan latar belakang di atas, maka perlu dilakukan penelitian mengenai konsumsi cairan dan status hidrasi pada atlet sepak bola remaja.

\section{METODE}

Penelitian ini termasuk dalam ruang lingkup keilmuan gizi masyarakat dan merupakan penelitian observasional dengan menggunakan rancangan cross-sectional. Populasi dalam penelitian ini adalah semua atlet sepak bola lakilaki usia 13-16 tahun di Sekolah Sepak Bola 
Universitas Diponegoro Semarang. Besar sampel dalam penelitian ini adalah 47 orang. Subjek diambil dengan cara simple random sampling. Subjek dipilih berdasarkan kriteria inklusi yaitu tercatat sebagai murid Sekolah Sepak Bola Universitas Diponegoro Semarang, mengisi inform consent, tidak demam, dan tidak mengalami diare.

Pengambilan data dilakukan pada bulan Juni 2014. Latihan yang dilakukan merupakan latihan pertandingan selama 70 menit $(2 \times 35$ menit dan istirahat 15 menit) pada sore hari yang dimulai pukul 15.30 WIB. Data yang dikumpulkan dalam penelitian ini adalah karakteristik subjek, konsumsi cairan, kehilangan berat badan, volume urin, keringat yang hilang selama latihan, dan status hidrasi setelah latihan. Data karakteristik subjek diperoleh melalui wawancara langsung dengan menggunakan kuesioner meliputi nama dan tanggal lahir. Perhitungan indeks masa tubuh (IMT) dengan pengukuran langsung berat badan menggunakan timbangan digital dengan ketelitian $0,1 \mathrm{~kg}$ dan tinggi badan dengan menggunakan microtoise ketelitian $0,1 \mathrm{~cm}$.

Konsumsi cairan adalah jumlah total cairan yang masuk dalam tubuh yang berasal dari minuman dan makanan yang diperoleh melalui food recall selama $1 \times 24$ jam. Konsumsi cairan yang diukur adalah konsumsi cairan sehari dan konsumsi cairan pada periode latihan. Konsumsi cairan sehari adalah jumlah total cairan yang dikonsumsi baik dari minuman maupun makanan yang diukur 24 jam sebelum latihan selesai. Konsumsi cairan selama periode latihan merupakan jumlah total konsumsi cairan sebelum, konsumsi cairan selama dan konsumsi cairan setelah latihan. Konsumsi cairan sebelum latihan adalah jumlah total cairan yang dikonsumsi baik dari minuman maupun makanan yang diukur 4 jam sebelum latihan dimulai. Konsumsi cairan 4 jam sebelum latihan dikatakan cukup jika mengonsumsi cairan minimal 600-900 $\mathrm{ml}^{14}$ Konsumsi cairan selama latihan adalah jumlah total cairan yang dikonsumsi baik dari minuman maupun makanan yang diukur selama latihan (70 menit). Konsumsi selama latihan 70 menit dikatakan cukup jika mengonsumsi minimal 700$1050 \mathrm{ml} .{ }^{14}$ Konsumsi cairan setelah latihan adalah jumlah total cairan yang dikonsumsi baik dari minuman maupun makanan yang diukur 1 jam setelah latihan selesai. Konsumsi cairan setelah latihan dikatakan cukup jika mengonsumsi 500$700 \mathrm{ml}$ setiap $0,5 \mathrm{~kg}$ berat badan yang hilang selama latihan. ${ }^{14,22,23}$ Konsumsi cairan periode latihan dikatakan cukup jika mengonsumsi 2400$3400 \mathrm{ml}$, sedangkan konsumsi cairan sehari dikatakan cukup jika mengonsumsi 5700-6700 ml. ${ }^{14}$ Perhitungan jumlah total konsumsi cairan menggunakan rumus pertambahan total cairan dari minuman dan total cairan dari makanan yang dilihat dari DKBM 2009.

Jenis minuman yang dikonsumsi dibagi menjadi 5, yaitu air, minuman karbohidrat, minuman elektrolit, minuman karbohidratelektrolit dan minuman berkarbonasi. Air adalah minuman yang jernih, tidak berasa dan tidak berbau. Minuman karbohidrat adalah minuman yang mengandung gula, contohnya teh, kopi, es, minuman rasa buah. Minuman elektrolit adalah minuman yang mengandung beberapa elektrolit seperti natrium, kalium, klorida, contohnya minuman ionisasi. Minuman karbohidrat-elektrolit adalah minuman yang mengandung gula dan beberapa elektrolit seperti natrium, kalium, klorida, contohnya jus buah atau sayuran, susu, sport drink. Minuman berkarbonasi adalah minuman yang dibuat dengan melarutkan gas karbondioksida dalam air minum, minuman ini sering disebut minuman soda.

Kehilangan berat badan merupakan selisih berat badan sebelum dan setelah latihan. Pengukuran berat badan sebelum latihan dilakukan \pm 30 menit sebelum latihan sedangkan berat badan setelah latihan dilakukan langsung setelah latihan selesai dengan menggunakan timbangan digital dengan ketelitian $0,1 \mathrm{~kg} .{ }^{5,12}$ Sebelum dilakukan pengukuran berat badan setelah latihan, subjek tidak diijinkan mengkonsumsi minuman atau makanan.

Volume urin adalah jumlah urin yang keluar selama dan setelah latihan selesai untuk menghitung keringat yang hilang selama latihan. Pengukuran volume urin menggunakan gelas ukur dengan ketelitian $1 \mathrm{ml}$. Semua volume urin yang diperoleh adalah urin setelah latihan.

Keringat yang hilang selama latihan adalah keringat yang dikeluarkan atlet selama latihan dilakukan. Keringat yang hilang selama latihan dapat dihitung dengan menggunakan rumus: (Berat Badan Sebelum Latihan - Berat Badan Setelah Latihan) + Konsumsi Cairan Selama Latihan Volume urin. ${ }^{14,24}$

Status hidrasi setelah latihan adalah suatu kondisi yang menggambarkan keseimbangan cairan dalam tubuh atlet setelah latihan yang dapat diketahui dengan cara pemeriksaan berat jenis urin (BJU). Metode berat jenis urin (BJU) dipilih karena mudah dilaksanakan, sering digunakan, waktu analisis singkat, ketepatan baik, biaya terjangkau, portabilitas alat baik, dan rendahnya risiko bagi subjek. ${ }^{25,34}$ 
Pengambilan sampel urin dilakukan selama 1 jam setelah latihan dengan menggunakan botol kaca bening. Pemeriksaan BJU dilakukan di laboratorium dengan menggunakan metode reagent strip. BJU dikategorikan menjadi empat, yaitu well-hydrated apabila nilai BJU $<1.010 \mathrm{~g} / \mathrm{dl}$, minimal dehydration apabila nilai BJU 1.010$1.020 \mathrm{~g} / \mathrm{dl}$, significant dehydration apabila nilai BJU 1.021-1.030 g/dl, dan seriously dehydration apabila nilai BJU >1.030 g/dl. ${ }^{14,26}$

Analisis univariat digunakan untuk mendeskripsikan masing-masing variabel. Analisis hubungan konsumsi cairan periode latihan dengan status hidrasi setelah latihan dan hubungan keringat yang hilang selama latihan dengan status hidrasi setelah latihan pada atlet sepak bola remaja menggunakan uji rank Spearman, yang sebelumnya diuji normalitas data dengan menggunakan uji Saphiro-Wilk.

\section{HASIL PENELITIAN \\ Karakteristik Subjek}

Jumlah subjek pada penelitian ini adalah 47 atlet sepak bola remaja laki-laki. Usia subjek berkisar antara 13-16 tahun dengan rata-rata tinggi badan $160,96 \pm 8,32 \mathrm{~cm}$, berat badan $50,17 \pm 9,24 \mathrm{~kg}$, dan IMT $19,21 \pm 2,25 \mathrm{~kg} / \mathrm{m}^{2}$. Karakteritik subjek penelitian dapat dilihat pada tabel 1 .

Tabel 1. Karakteristik Subjek berdasarkan Usia, Tinggi Badan, IMT dan Berat Jenis Urin

\begin{tabular}{lccc}
\hline \multirow{2}{*}{ Karakteristik Subjek } & \multicolumn{3}{c}{$\mathbf{n = 4 7}$} \\
\cline { 2 - 4 } & Minimum & Maximum & Rerata \pm SD \\
\hline Usia (tahun) & 13 & 16 & $14,47 \pm 1,08$ \\
Tinggi Badan $(\mathrm{cm})$ & 136,9 & 173,6 & $160,96 \pm 8,32$ \\
Berat Badan $(\mathrm{kg})$ & 31,8 & 73,4 & $50,17 \pm 9,24$ \\
IMT $\left(\mathrm{kg} / \mathrm{m}^{2}\right)$ & 14,8 & 24,7 & $19,21 \pm 2,25$ \\
Berat Jenis Urin $(\mathrm{g} / \mathrm{dl})$ & 1.015 & 1.030 & $1.028 \pm 0,004$ \\
\hline
\end{tabular}

\section{Konsumsi Cairan Atlet Sepak Bola Remaja}

Konsumsi cairan sehari subjek berkisar antara 1641,8-4534,6 $\mathrm{ml}$ dengan rerata $3050,92 \pm 631,70 \mathrm{ml}$, sedangkan konsumsi cairan periode latihan berkisar antara 929,8-2846,7 ml dengan rerata $1678,77 \pm 457,99 \mathrm{ml}$. Konsumsi cairan periode latihan menyumbang $55 \%$ dari konsumsi cairan sehari. Rerata konsumsi cairan subjek sebelum, selama dan setelah latihan adalah $752,16 \pm 277,58 \mathrm{ml}, \quad 512,02 \pm 247,71 \mathrm{ml}$ dan $414,59 \pm 197,16 \mathrm{ml}$. Konsumsi cairan atlet sepak bola remaja dapat dilihat pada tabel 2 .

Tabel 2. Nilai minimum, maksimum, rerata dan standar deviasi Konsumsi Cairan Sehari dan Konsumsi Cairan Periode Latihan

\begin{tabular}{lccc}
\hline \multirow{2}{*}{ Konsumsi Cairan } & \multicolumn{3}{c}{$\mathbf{n = 4 7}$} \\
\cline { 2 - 4 } & Minimum & Maksimum & Rerata \pm SD \\
\hline Konsumsi Cairan Sehari (ml) & 1641,8 & 4534,6 & $3050,92 \pm 631,70$ \\
Konsumsi Cairan Periode Latihan $(\mathrm{ml})$ & 929,8 & 2846,7 & $1678,77 \pm 457,99$ \\
Konsumsi Cairan Sebelum Latihan $(\mathrm{ml})$ & 300 & 1646,7 & $752,16 \pm 277,58$ \\
Konsumsi Cairan Selama Latihan $(\mathrm{ml})$ & 120 & 1350 & $512,02 \pm 247,71$ \\
Konsumsi Cairan Setelah Latihan $(\mathrm{ml})$ & 150 & 960 & $414,59 \pm 197,16$ \\
\hline
\end{tabular}

Berdasarkan hasil penelitian, hampir semua subjek menunjukkan bahwa konsumsi cairan sehari maupun konsumsi cairan periode latihan dalam kategori kurang. Lebih dari separuh subjek $(68,1 \%)$ mengkonsumsi cairan yang cukup sebelum latihan. Namun, $>80 \%$ subjek mengonsumsi cairan yang kurang selama dan setelah latihan. Distribusi frekuensi kategori konsumsi cairan dapat dilihat pada tabel 3.

Tabel 3. Distribusi Frekuensi Kategori Konsumsi Cairan

\begin{tabular}{|c|c|c|c|c|c|c|}
\hline \multirow{3}{*}{ Konsumsi Cairan } & \multicolumn{4}{|c|}{ Kategori } & \multirow{2}{*}{\multicolumn{2}{|c|}{ Total }} \\
\hline & \multicolumn{2}{|c|}{ Kurang } & \multicolumn{2}{|c|}{ Cukup } & & \\
\hline & $\mathbf{n}$ & $\%$ & $\mathbf{n}$ & $\%$ & $\mathbf{n}$ & $\%$ \\
\hline Konsumsi Cairan Sehari (ml) & 47 & 100 & - & - & 47 & 100 \\
\hline Konsumsi Cairan Periode Latihan (ml) & 45 & 95,7 & 2 & 4,3 & 47 & 100 \\
\hline Konsumsi Cairan Sebelum (ml) & 15 & 31,9 & 32 & 68,1 & 47 & 100 \\
\hline Konsumsi Cairan Selama (ml) & 38 & 80,9 & 9 & 19,1 & 47 & 100 \\
\hline Konsumsi Cairan Setelah (ml) & 42 & 89.4 & 5 & 10,6 & 47 & 100 \\
\hline
\end{tabular}


Jenis konsumsi cairan sehari dan periode latihan dapat dilihat pada tabel 4 .

Tabel 4. Nilai minimum, maksimum, rerata dan standar deviasi jenis konsumsi cairan sehari dan periode latihan

\begin{tabular}{lccc}
\hline \multicolumn{1}{c}{ Jenis Konsumsi Cairan } & \multicolumn{2}{c}{$\mathbf{n = 4 7}$} \\
\cline { 2 - 4 } Konsumsi Cairan Sehari & Minimum & Maksimum & Rerata \pm SD \\
Air (ml) & 480 & 3275 & $1731,14 \pm 628,59$ \\
Minuman lain (ml) & 0 & 2000 & $851,33 \pm 473,21$ \\
Cairan dari makanan (ml) & 26,6 & 882,1 & $468,44 \pm 178,38$ \\
& & & \\
Konsumsi Cairan Periode Latihan & 480 & 2205 & $1166,70 \pm 459,46$ \\
Air (ml) & 0 & 1465 & $377,50 \pm 318,74$ \\
Minuman lain (ml) & 0 & 336,4 & $134,57 \pm 94,4$ \\
Cairan dari makanan (ml) & & & \\
\hline
\end{tabular}

Total konsumsi cairan diperoleh dari air, minuman lain dan cairan dari makanan. Konsumsi air lebih banyak dibanding konsumsi minuman lain maupun cairan dari makanan. Rerata konsumsi air, minuman lain dan cairan dari makanan pada konsumsi cairan sehari adalah $1731,14 \pm 628,59 \mathrm{ml}$, $851,33 \pm 473,21 \mathrm{ml}$ dan $468,44 \pm 178,38 \mathrm{ml}$. Konsumsi air menyumbang sebesar $56,7 \%$ dari total konsumsi cairan sehari sedangkan minuman lain menyumbang sebesar $27,9 \%$ dan cairan dari makanan sebesar 15,4\%. Rerata konsumsi air, minuman lain dan cairan dari makanan pada konsumsi cairan periode latihan adalah $1166,70 \pm 459,46 \mathrm{ml}, \quad 377,50 \pm 318,74 \mathrm{ml}$ dan $134,57 \pm 94,4 \mathrm{ml}$. Konsumsi air menyumbang sebesar $69,5 \%$ dari total konsumsi cairan periode latihan sedangkan minuman lain menyumbang sebesar $22,5 \%$ dan cairan dari makanan sebesar $8 \%$. Jenis minuman yang dikonsumsi oleh subjek pada periode latihan dapat dilihat pada tabel 5 .

Tabel 5. Distribusi Frekuensi jenis minuman yang dikonsumsi pada periode latihan

\begin{tabular}{lcccccc}
\hline \multirow{2}{*}{ Jenis Minuman } & \multicolumn{2}{c}{ Sebelum Latihan } & \multicolumn{2}{c}{ Selama Latihan } & \multicolumn{2}{c}{ Setelah Latihan } \\
\cline { 2 - 7 } & $\mathrm{n}$ & $\%$ & $\mathrm{n}$ & $\%$ & $\mathrm{n}$ & $\%$ \\
\hline Air & 39 & 82,9 & 46 & 97,9 & 44 & 93,6 \\
Minuman karbohidrat & 22 & 46,8 & 8 & 17,0 & 5 & 10,6 \\
Minuman elektrolit & - & - & 4 & 8,5 & 1 & 2,1 \\
Minuman karbohidrat-elektrolit & 6 & 12,7 & - & - & - & - \\
Minuman berkarbonasi & 1 & 2,1 & - & - & - & - \\
\hline
\end{tabular}

Konsumsi cairan sebelum latihan sebagian besar berasal dari air (82,9\%), diikuti oleh minuman karbohidrat $(46,8 \%)$, minuman karbohidrat-elektrolit $(12,7 \%)$ dan minuman berkarbonasi $(2,1 \%)$. Konsumsi cairan selama latihan sebagian besar berasal dari air $(97,9 \%)$. Hanya sedikit yang mengkonsumsi minuman karbohidrat $(17,0 \%)$ dan minuman elektrolit $(8,5 \%)$. Konsumsi cairan setelah latihan juga sebagian besar berasal dari air $(93,6 \%)$ dan hanya beberapa yang mengonsumsi minuman karbohidrat $(10,6 \%)$ dan minuman elektrolit $(2,1 \%)$. Selama latihan dan setelah latihan, tidak ada atlet yang mengonsumsi minuman karbohidrat-elektrolit.

Kehilangan Berat Badan dan Keringat yang Hilang Selama Latihan

Nilai minimum, maksimum, rerata dan standar deviasi kehilangan berat badan, volume urin dan keringat yang hilang selama latihan dapat dilihat pada tabel 6 .

Tabel 6. Nilai minimum, maksimum, rerata dan standar deviasi kehilangan berat badan, volume urin dan keringat yang hilang selama latihan

\begin{tabular}{lccc}
\hline \multicolumn{1}{c}{ Karakteristik } & \multicolumn{3}{c}{$\mathbf{n = 4 7}$} \\
\cline { 2 - 4 } & Minimum & Maximum & Rerata \pm SD \\
\hline Kehilangan Berat Badan (kg) & 0,2 & 2,2 & $0,88 \pm 0,46$ \\
Persen Kehilangan Berat Badan (\%) & 0,5 & 4,4 & $1,77 \pm 0,87$ \\
Volume urin (ml) & 8 & 65 & $32,94 \pm 13,53$ \\
Keringat yang hilang selama latihan (ml) & 645 & 2640 & $1364,19 \pm 448,68$ \\
\hline
\end{tabular}


Semua subjek mengalami kehilangan berat badan selama latihan. Kehilangan berat badan subjek berkisar antara 0,2-2,2 $\mathrm{kg}$ dengan rerata $0,88 \pm 0,46 \mathrm{~kg}$, sedangkan persen kehilangan berat badan subjek berkisar antara $0,5-4,4 \%$ dengan rerata $1,77 \pm 0,87 \%$. Terdapat 3 subjek yang mengalami kehilangan berat badan sebesar 3-5\% . Rerata jumlah volume urin adalah $32,94 \pm 13,53 \mathrm{ml}$. Keringat yang hilang selama latihan berkisar antara 645-2640 ml dengan rerata 1364,19 $\pm 448,68 \mathrm{ml}$.

\section{Status Hidrasi Setelah Latihan}

Hasil pengukuran berat jenis urin menunjukkan bahwa $100 \%$ subjek mengalami dehidrasi (BJU $\geq 1.010 \mathrm{~g} / \mathrm{dl}$ ). Sebagian besar mengalami significant dehydration $(89,4 \%)$ dan sisanya mengalami minimal dehydration $(10,6 \%)$. Status hidrasi pada atlet sepak bola remaja dapat dilihat pada tabel 7 .

Tabel 7. Distribusi Frekuensi Status Hidrasi Setelah Latihan

\begin{tabular}{lcc}
\hline \multicolumn{1}{c}{ Status Hidrasi } & Frekuensi (n) & Persentase (\%) \\
\hline Minimal dehydration & 5 & 10,6 \\
Significant dehydration & 42 & 89,4 \\
\hline Total & 47 & 100 \\
\hline
\end{tabular}

\section{Hubungan Konsumsi Cairan Periode Latihan dan Keringat yang hilang Selama Latihan dengan Status Hidrasi Setelah Latihan}

Hasil penelitian menunjukkan bahwa terdapat hubungan yang bermakna antara konsumsi cairan periode latihan dan status hidrasi setelah latihan pada atlet sepak bola remaja $(p<0,05)$ dan menunjukkan arah korelasi negatif $(r=-0,297)$.
Sementara itu, tidak terdapat hubungan yang bermakna antara keringat yang hilang selama latihan dan status hidrasi setelah latihan pada atlet sepak bola remaja $(p>0,05)$. Hubungan konsumsi cairan periode latihan dan keringat yang hilang selama latihan dengan status hidrasi setelah latihan dapat dilihat pada tabel 8.

Tabel 8 . Hubungan konsumsi cairan periode latihan dan keringat yang hilang selama latihan dengan status hidrasi setelah latihan

\begin{tabular}{lcc}
\hline \multirow{2}{*}{ Variabel } & \multicolumn{2}{c}{ Status Hidrasi setelah latihan $(\mathbf{g} / \mathbf{d l})$} \\
\cline { 2 - 3 } & $\mathrm{r}$ & $\mathrm{p}$ \\
\hline Konsumsi Cairan Periode Latihan $(\mathrm{ml})$ & $-0,297$ & $0,043^{\mathrm{S}}$ \\
Keringat yang hilang selama latihan $(\mathrm{ml})$ & 0,087 & $0,559^{\mathrm{NS}}$ \\
\hline Catatan: S : Significant $(\mathrm{p}<0,05)$ & $\mathrm{NS}:$ Not Significant
\end{tabular}

\section{PEMBAHASAN}

Hasil penelitian menunjukkan bahwa konsumsi cairan sehari semua subjek dalam kategori kurang. Hal ini menunjukkan bahwa semua atlet belum mampu memenuhi kebutuhan cairan sehari. Hampir semua subjek $(95,7 \%)$ menunjukkan konsumsi cairan yang kurang pada periode latihan. Konsumsi cairan yang kurang dapat terjadi karena kurangnya pengaturan konsumsi cairan oleh atlet saat periode latihan yaitu sebelum, selama dan setelah latihan. Beberapa penelitian menunjukkan bahwa banyak atlet sepak bola mengkonsumsi cairan yang kurang saat latihan maupun pertandingan. $5,12,16,18,21$ Konsumsi cairan yang tepat sebelum, selama dan setelah latihan diperlukan atlet untuk menjaga status hidrasi dan menunjang performa olahraga. Namun, kebutuhan cairan akan semakin meningkat apabila aktifitas fisik semakin tinggi dan suhu semakin panas. ${ }^{10}$ Sepak bola merupakan olahraga yang tingkat aktifitasnya tinggi karena dalam suatu pertandingan atlet dapat menempuh jarak $\pm 10 \mathrm{~km} .{ }^{4}$ Semakin tinggi aktifitas maka panas yang dihasilkan oleh metabolisme energi juga akan meningkat. Cairan yang berada di dalam tubuh akan menjalankan fungsinya sebagai pengatur panas (thermoregulator). Fungsi ini dijalankan dengan tujuan agar temperatur internal tubuh (core temperature) dapat tetap terjaga. Air akan mengeluarkan kelebihan panas tubuh melalui keringat. Saat berolahraga, air yang keluar melalui keringat tidak hanya merupakan air yang dihasilkan melalui proses metabolisme namun juga air yang diperoleh melalui konsumsi cairan. Sehingga apabila proses berkurangnya cairan dari dalam tubuh pada saat berolahraga dibiarkan dalam jangka waktu yang lama dan tidak diimbangi dengan konsumsi cairan yang cukup maka tubuh akan mengalami dehidrasi. ${ }^{31}$

Hasil penelitian menunjukkan bahwa sebagian besar konsumsi cairan sebelum latihan adalah cukup. Hal ini karena pengukuran konsumsi 
cairan sebelum latihan dilakukan 4 jam sebelum latihan dimulai sehingga atlet mempunyai banyak kesempatan untuk mengakses makanan dan minuman. Selama latihan, ditemukan banyak atlet yang konsumsi cairannya kurang. Atlet dianjurkan untuk mengonsumsi cairan 200-300 ml setiap 1020 menit tetapi dalam penelitian ini waktu konsumsi cairan atlet terbatas karena hanya mengonsumsi makanan atau minuman saat istirahat saja. Hampir semua konsumsi cairan atlet setelah latihan adalah kurang. Hal ini dikarenakan atlet kurang dapat memanfaatkan kesempatan dalam waktu 1 jam yang ada untuk mengakses makanan atau minuman. Padahal atlet dapat dengan mudah mengakses makanan atau minuman yang tersedia di kantin. Hal ini sama dengan penelitian yang menunjukkan bahwa atlet tidak memaksimalkan kesempatan untuk mengakses minuman yang disediakan. ${ }^{12}$ Konsumsi cairan atlet sebelum, selama dan setelah latihan yang kurang juga dapat disebabkan karena kurangnya pengetahuan terkait pentingnya konsumsi cairan saat latihan atau pertandingan. Sebuah studi di Porto menyatakan bahwa atlet yang memiliki pengetahuan mengenai status hidrasi, lebih memperhatikan jumlah konsumsi cairan saat latihan. ${ }^{27}$

Atlet memerlukan pengaturan minum yang tepat sebelum latihan supaya dapat memulai latihan dengan status hidrasi yang baik. Sebelum latihan, atlet dapat mengkonsumsi berbagai jenis minuman, antara lain air, jus buah atau sayuran, susu, dan sport drink. ${ }^{14}$ Jenis minuman yang paling banyak dikonsumsi sebelum latihan adalah air tetapi terdapat 1 subjek yang mengonsumsi minuman berkarbonasi. Minuman berkarbonasi sebaiknya dihindari karena gas dalam minuman dapat membuat perut terasa penuh sehingga menurunkan jumlah konsumsi cairan. ${ }^{14}$ Konsumsi cairan selama latihan sebagian besar berasal dari air. Hanya sedikit yang mengkonsumsi minuman karbohidrat dan minuman elektrolit. Atlet disarankan mengkonsumsi minuman yang mengandung 6-8\% karbohidrat dan elektrolit terutama natrium, selama latihan untuk menjaga level glukosa darah dan menggantikan elektrolit yang hilang melalui keringat. ${ }^{14}$ Elektrolit utama yang hilang melalui keringat saat latihan adalah natrium dan klorida. Jika elektrolit yang hilang melalui keringat tidak dapat digantikan akan mempengaruhi keseimbangan cairan dalam tubuh dan performa olahraga. ${ }^{14}$ Minuman yang disarankan adalah jus buah atau sayuran, susu, dan sport drink. ${ }^{14,28,29}$ Setelah latihan, atlet perlu melakukan rehidrasi yang bertujuan untuk menggantikan cairan dan elektrolit yang hilang saat latihan. ${ }^{13,20}$ Minuman yang disarankan adalah minuman yang mengandung karbohidrat dan elektrolit, antara lain jus buah atau sayuran, susu, dan sport drink..$^{14,28,29}$ Namun, dalam penelitian ini sebagian besar subjek mengonsumsi air dan hanya beberapa yang mengonsumsi minuman karbohidrat maupun minuman elektrolit. Jika hanya mengkonsumsi air tidak menstimulasi rasa ingin minum dan dapat meningkatkan jumlah urin yang keluar yang menyebabkan penurunan asupan dan meningkatkan keluaran. $^{14}$ Minuman elektrolit terutama yang mengandung natrium akan meningkatkan retensi cairan dan menstimulasi rasa ingin minum. ${ }^{14}$

Hasil penelitian menujukkan bahwa subjek mengalami kehilangan berat badan $0,5-4,4 \%(0,2-$ $2,2 \mathrm{~kg}$ ). Sebagian besar subjek kehilangan berat badan sebesar $1-3 \%$ tetapi terdapat 3 subjek yang mengalami kehilangan berat badan sebesar 3-5\% . Kehilangan berat badan setelah latihan pada atlet menunjukkan kehilangan cairan dalam tubuh. ${ }^{11,14}$ Kehilangan cairan tubuh disebabkan oleh aktivitas fisik yang tinggi dan tidak diimbangi dengan konsumsi cairan yang cukup. Atlet sepak bola mempunyai sedikit kesempatan mengakses minuman selama latihan sehingga tidak mengherankan apabila kehilangan berat badan 1$3 \%$ atau lebih. ${ }^{30}$ Penelitian di Brazil menunjukkan bahwa atlet sepak bola remaja mengalami kehilangan berat badan sebesar 0,59-3,15\% (0,4$2,1 \mathrm{~kg}$ ).

Apabila atlet kehilangan cairan 1-3\% dari berat tubuh dapat menyebabkan rasa haus yang kuat, kehilangan cita rasa, perasaaan tidak nyaman, peningkatan denyut jantung, dan penurunan performa olahraga sebesar $10 \% .^{9,14,31,32}$ Kehilangan cairan 3-5\% dari berat tubuh dapat menyebabkan mulut kering, rasa tidak sabar, penurunan volume darah, sulit konsentrasi, gemetar berlebihan, aktifitas fisik melambat, lesu, muntah, emosi tidak stabil, dan penurunan performa sebesar $30 \% .^{9}{ }^{914,31,32}$ Salah satu penelitian menunjukkan bahwa dehidrasi dengan kehilangan cairan sebesar $1,5-2 \%$ dari berat badan dapat menurunkan performa psikologi dalam performa sepak bola. ${ }^{33}$

Hasil penelitian ini menunjukkan bahwa atlet sepak bola remaja rata-rata kehilangan keringat sebanyak 1364,19 $\pm 448,68 \mathrm{ml}(645-2640$ $\mathrm{ml}$ ). Nilai maksimum keringat yang hilang selama latihan pada penelitian ini hampir sama dengan nilai maksimum keringat yang hilang selama latihan pada penelitian di Amerika meskipun dengan lama latihan yang berbeda. Penelitian di Amerika menunjukkan bahwa atlet sepak bola 
kehilangan keringat sebanyak 1060-2650 ml setelah dilakukan latihan selama 90 menit. $^{16}$ Penelitian di Brazil menunjukkan pemain sepak bola remaja rata-rata kehilangan keringat $>2$ liter (1,48-3,25 liter) setelah melakukan latihan selama 80 menit. $^{21}$ Keringat yang hilang selama latihan dipengaruhi oleh beberapa faktor, antara lain suhu lingkungan, intensitas dan lama latihan, usia dan jenis kelamin, kelembaban udara serta pakaian yang digunakan..$^{10,14,34}$ Banyaknya keringat yang hilang dalam penelitian ini disebabkan karena intensitas yang tinggi dalam olahraga sepak bola. Beberapa literatur menyebutkan bahwa suhu lingkungan, kelembaban udara dan kecepatan angin adalah faktor yang paling berpengaruh terhadap keringat yang hilang. ${ }^{16,29}$ Namun, dalam penelitian ini tidak dilakukan pengukuran suhu lingkungan maupun kelembaban udara.

Hasil pengukuran berat jenis urin menunjukkan bahwa semua subjek mengalami dehidrasi (BJU $\geq 1.010 \mathrm{~g} / \mathrm{dl}$ ). Sebagian besar subjek mengalami significant dehydration $(89,4 \%)$ dan sisanya mengalami minimal dehydration $(10,6 \%)$. Penelilitian di Yunani pada atlet sepak bola remaja menunjukkan bahwa 94 dari 107 pemain mengalami dehidrasi sebelum latihan dengan BJU $\geq 1.020 \mathrm{~g} / \mathrm{dl} .{ }^{17}$ Penelitian lain di Turki pada atlet sepak bola yang melakukan latihan selama 90 menit menunjukkan bahwa sebelum latihan $60 \%$ mengalami significant dehydration dan 5\% mengalami seriously dehydration, kemudian setelah latihan $55 \%$ mengalami significant dehydration dan $35 \%$ mengalami seriously dehydration. ${ }^{15}$

Hasil penelitian menunjukkan tidak terdapat hubungan yang bermakna antara keringat yang hilang selama latihan dan status hidrasi setelah latihan $(p>0,05)$. Namun, secara statistik menunjukkan arah korelasi positif $(\mathrm{r}=0,087)$. Artinya, semakin tinggi keringat yang hilang maka nilai berat jenis urin juga semakin tinggi. Seorang atlet dapat kehilangan air 90\% melalui keringat selama latihan pada suhu yang panas. ${ }^{8}$ Oleh karena itu, jika kehilangan cairan melalui keringat tidak diimbangi dengan konsumsi cairan yang cukup maka juga akan menyebabkan dehidrasi. Tidak terdapatnya hubungan pada penelitian ini mungkin disebabkan karena keringat yang hilang saat latihan tidak langsung mempengaruhi status hidrasi. Cairan yang dikonsumsi atlet selama dan setelah latihan masih dapat menggantikan cairan yang hilang melalui keringat.

Hasil penelitian menunjukkan bahwa terdapat hubungan yang bermakna antara konsumsi cairan pada periode latihan dan status hidrasi setelah latihan pada atlet sepak bola remaja $(\mathrm{p}<0,05)$ dan menunjukkan arah korelasi negatif $(\mathrm{r}$ $=-0,297)$ artinya semakin tinggi konsumsi cairan, maka nilai berat jenis urin akan semakin rendah. Hasil tersebut sesuai dengan teori dan hipotesis. Saat kekurangan asupan cairan maupun kehilangan cairan secara berlebih, di dalam darah terjadi peningkatan osmolalitas sehingga darah menjadi hipertonik. Osmoreseptor di dalam hipotalamus mendeteksi peningkatan osmolalitas darah sehingga menstimulasi kelenjar ptituary untuk mensekresi antidiuretic hormon (ADH). ADH menstimulasi ginjal untuk meningkatkan absorbsi air. Hal ini menyebabkan penurunan jumlah keluaran urin dan peningkatan konsentrasi urin. ${ }^{14,35,36}$ Saat yang sama, osmoreseptor juga menstimulasi rasa haus supaya mengonsumsi cairan dan digunakan untuk mengembalikan keseimbangan cairan dalam tubuh. Saat latihan, atlet sebaiknya tidak bergantung pada rasa haus tetapi melakukan pengaturan minum yang tepat sebelum, selama dan setelah latihan untuk menjaga keseimbangan cairan tubuh dan performa olahraga.

\section{SIMPULAN}

Konsumsi cairan atlet pada periode latihan masih kurang dari kebutuhan sehingga sebagian besar atlet mengalami significant dehydration $(89,4 \%)$ dan lainnya mengalami minimal dehydration (10,6\%). Terdapat hubungan yang bermakna antara konsumsi cairan periode latihan dan status hidrasi setelah latihan, tetapi tidak terdapat hubungan yang bermakna antara keringat yang hilang selama latihan dan status hidrasi setelah latihan pada atlet sepak bola remaja.

\section{SARAN}

Perlu peningkatan konsumsi cairan bagi atlet sepak bola remaja sesuai kebutuhan (2400$3400 \mathrm{ml}$ ) saat periode latihan untuk mencegah terjadinya dehidrasi. Hal ini dapat dilakukan atlet dengan membiasakan diri membawa botol minum sendiri saat latihan. Selain itu, juga diperlukan edukasi tentang pentingnya konsumsi cairan pada atlet dan pengaturan konsumsi cairan sebelum, selama dan setelah latihan, meliputi jumlah, jenis, dan jadwal agar atlet dapat mencapai status hidrasi yang baik saat latihan maupun pertandingan.

\section{DAFTAR PUSTAKA}

1. Kementrian Pemuda dan Olahraga Republik Indonesia. Penyajian Data dan Informasi Statistik Keolahragaan Tahun 2010. 2010. 
2. Sudiana IK. Asupan Nutrisi Seimbang sebagai Upaya Mencegah Kemerosotan Prestasi Olahraga. 2007.

3. Kirkendall DT. Creatine, Carbs and Fluids: How Important in Soccer Nutrition?. Sport Science Exchange Vol 17 Number 3. 2004.

4. Irawan, MA. Cairan, Karbohidrat \& Performa Sepakbola. Sport Science Brief. 2007.

5. Silva RP, Toby M, Antonio JN, Maurico GBF, Jorge RPL, et all. Fluid balance of elite Brazilian youth soccer players during consecutive days of training. Journal of Sport Science. 2011; 29 (7): 725-732.

6. Singh R. Fluid Balance and Exercise Performance. Mal J Nutr 9(1): 53-74, 2003.

7. Bangsbo J, Magni M, Peter K. Physical and metabolic demands of training and match-play in the elite football player. Journal of Sport Science, 2006; 24 (7): 665-674.

8. Armstrong, Lawrence. Assesing Hydration Status: The Elusive Gold Standard. Journal of the American College of Nutrition. 2007; 26 (14): 575-584.

9. Santoso BI, Hardinsyah. 2011. Air bagi Kesehatan. Jakarta: Centra Communications.

10. Kenefick RW, Samuel NC, Lisa L, Karen KO. Dehydration and Rehydration. Book Chapter Wilderness Medicine Textbook. 2012.

11. Coyle, EF. Fluid and Fuel Intake during Exercise. Journal of Sport Science. 2004; 22 (16): 39-55.

12. Kurdak SS, et all. Hydration and sweating responses to hot-weather football competition. Scand J Med Sci Sports. 2010; 20 (7): 133-139.

13. Sawka MN, Louise MB, E Randy E, Ronald JM, Scott JM, Nina SS. Exercise and Fluid Replacement. American College and Sport Medicine. 2007.

14. Fink HH, Alan EM, Lisa AB. 2013. Practical Applications in Sport Nutrition $3^{\text {rd }}$ ed. Canada: Jones and Bartlett Publishers.

15. Ozolina L, Inese P, Madara S. Body Hydration Degree Changes During Training in Football Players in Winter Conditions. Journal of Sport Science. 2013.

16. Maughan, RJ. Fluid and electrolyte balance in elite male football (soccer) players training in a cool environtment. Journal of Sport Science. 2005; 23(7): 73-79.

17. Arnaoutis G, Stavros AK, Yiannis PK, Yiannis ET, Michalis M, Costas NB. Ad Libitum Fluid Intake Does Not Prevent Dehydration in Suboptimally Hydrated Young Soccer Players During a Training Session of a Summer Camp. International Journal of Sport Nutrition and Exercise Metabolism. 2013 (7): 245-251.

18. Yeargin SW. Thermoregulatory Responses and Hydration Practices in Heat-Acclimated Adolescents During Preseason High School Football. Journal of Athletic Training. 2010; 45 (10): 136-146.

19. Hoch AZ. Nutritional Requirements of the Chlid and Teenage Athlete. Phys Med Rehabil Clin N Am. 2008 (19): 373-398.
20. Stang J. Nutrition in Adolescence. In: Mahan LK, Sylvia ES, Janice LS. Krause's Food and the Nutrition Care Process; 2012. p427.

21. Da Silva, RP. Pre-game Hydration Status, Sweat Loss, and Fluid Intake in Elite Brazilian Young Male Soccer Player during Competition. Journal of Sports Science. 2012; 30(6): 37-42.

22. Ronald H. Metoda Rehidrasi USATF sebagai Metode Alternatif Pemulihan Cairan Tubuh. Seminar Nasional. 2009.

23. Goldberg B. Health Concerns for Young Athletes Book 4: Play Safe! The NFL Youth Football Health and Safety Series. Book Series National Football League. 2003.

24. Lopez RM. Exercise and Hydration: Individualizing Fluid Replacement Guidelines. Strength and Conditioning Journal. 2012.

25. Santoso BI, Hardinsyah. 2011. Air bagi Kesehatan. Jakarta: Centra Communications.

26. Casa DJ. National Athletic Trainers' Association Position Statemen : Fluid Replacement for Atheletes. Journal of Athletic Training. 2000; 35(2): 212-224.

27. Carvalho PR, Teixeira VH, Oliveira B. Impact of Fluid Restriction and Ad Libitum Sports Drinks and Water Intake on Skill Performance of Elite Adolescent Basketball Players. Journal of Nutrition Faculty, Porto University Volume 15 No 2. 2009.

28. Kirkendall DT. Creatine, Carbs and Fluids: How Important in Soccer Nutrition?. Sport Science Exchange Vol 17 Number 3. 2004.

29. Shirreffs SM. Hydration in sport and exercise: water, sports drink and other drinks. Journal compilation. 2009; (34): 374-379.

30. Aragon-Vargas LF, Jose MJ, Jessenia HE, Alvaro BC, Maria MA. Evaluation of pre-game hydration status, heat stress, and fluid balance during professional soccer competition in the heat. European Journal of Sport Science, (2009) 9:5,269276.

31. Irawan MA. Konsumsi Cairan dan Olahraga. Sport Science Brief. 2007.

32. Thompson JL, Melinda MM, Linda AV. 2011. The Science of Nutrition $2^{\text {nd }}$ Ed. San Francisco: Pearson Benjamin Cummings.

33. Edwards AM, Michael EM, Michael JMJ, Dean MR, Timothy DN, David PS. Influence of moderate dehydration on soccer performance: physiological responses to $45 \mathrm{~min}$ of outdoor match-play and the immediate subsequent performance of sport-specific and mental concentration tests. Br J Sports Med 2007;41:385-391.

34. Driskell J, Ira W. 2011. Nutritional Assesment of Athletes 2nd Ed. America: CRC Press.

35. Jeqiuer E, F Constant. Water as an essential nutrient: the Physiological basis of hydration. European Journal of Clinical Nutrition. (2010) 64, 115-123. Popkin BM, Kristen ED, Irwin HP. Water, Hydration and Health. Nutr Rev. 2010; 68(8): 439458. 